Article

\title{
Promoting or Inhibiting? The Impact of Enterprise Environmental Performance on Economic Performance: Evidence from China's Large Iron and Steel Enterprises
}

\author{
Rong Liu ${ }^{1}$, Feng $\mathrm{He}^{1,2, *}$ and Jianyu Ren ${ }^{3}$ \\ 1 School of Economics and Management, University of Science and Technology Beijing, Beijing 100083, China; \\ b20170402@xs.ustb.edu.cn \\ 2 School of Economics and Management, Hubei Normal University, Huangshi 435002, China \\ 3 School of Economics, Zhejiang Gongshang University, Hangzhou 310018, China; jyren@mail.zjgsu.edu.cn \\ * Correspondence: hefeng@manage.ustb.edu.cn
}

Citation: Liu, R.; He, F.; Ren, J.

Promoting or Inhibiting? The Impact of Enterprise Environmental

Performance on Economic

Performance: Evidence from China's

Large Iron and Steel Enterprises.

Sustainability 2021, 13, 6465. https:/ /

doi.org/10.3390/su13116465

Academic Editor: Alan Randall

Received: 25 April 2021

Accepted: 31 May 2021

Published: 7 June 2021

Publisher's Note: MDPI stays neutral with regard to jurisdictional claims in published maps and institutional affiliations.

Copyright: (c) 2021 by the authors. Licensee MDPI, Basel, Switzerland. This article is an open access article distributed under the terms and conditions of the Creative Commons Attribution (CC BY) license (https:/ / creativecommons.org/licenses/by/ $4.0 /)$.

\begin{abstract}
In recent years, the importance of corporate environmental responsibility has gradually become more prominent. This study combines the Slack-based Measurement (SBM) model with the "Super-efficiency" model to construct an environmental performance evaluation based on Data Envelopment Analysis (DEA), which is used to measure the environmental performance of China's large iron and steel enterprises from 2009 to 2017. Moreover, the impact of environmental performance on enterprise economic performance is studied by regression analysis. The results show that that environmental performance and economic performance of large iron and steel enterprises in China are in an inverted U-shaped relationship. This encourages enterprises to be proactive in environmental management to maintain and enhance their competitive edge. Therefore, this research suggests that iron and steel enterprises should balance the relationship between environmental performance and economic performance, and adopt environmental protection behaviors to carry out production and operation, to maximize enterprise performance.
\end{abstract}

Keywords: environmental performance; economic performance; iron and steel enterprises

\section{Introduction}

At present, green development is a priority for all countries. Under the dual pressure of economic growth and pollution control, it is vital to achieving a win-win situation of "reducing pollution" and "increasing efficiency" at the same time. Therefore, enterprises should bear environmental responsibilities while obtaining economic benefits to meet the environmental protection needs of stakeholders. How to balance ecological environmental protection and economic development is an important problem that urgently needs to be solved.

Due to the lack of environmental protection facilities, outdated technology, lax emission standards, and inadequate supporting regulations, industrial enterprises that are very important to China's economic structure have become the largest source of pollution. Environmental protection in industrial enterprises still has a long way to go. Due to the large scale of China's industrial economy and complicated production structure, it is impossible to achieve the cleaner production encouraged by the government. Therefore, improving the environmental and economic performance of industrial enterprises has become an important goal for national environmental governance [1].

As the main force of economic development, enterprises are not only responsible for market demand, but also for the protection of resources and the environment. In recent years, governments and environmental organizations in various countries have paid more and more attention to environmental protection, and enterprises are facing increasing pressure on environmental protection [2-4]. At present, China's share in world 
steel production and use has increased from less than $20 \%$ to more than $50 \%$. The steel industry has become a major contributor to China's economic growth. However, this rapid development is driven by an energy-intensive model, which has caused a series of environmental problems. The production and operation process of many iron and steel enterprises in China has a negative impact on the environment [5]. Facing increasingly serious environmental problems and pressure from the government, public, and other stakeholders, enterprises need to proactively assume environmental responsibilities and conduct environmental management. However, whether environmental management can lead to economic performance is one of the most concerning problems for enterprises. The impact of environmental responsibility on economic performance determines the production and management decisions of enterprises. Based on data from China's large iron and steel enterprises from 2009 to 2017, this study links corporate environmental responsibility with economic goals and discusses the impact of corporate environmental performance on economic performance. The main purpose of this study is to provide a theoretical and practical reference for Chinese iron and steel enterprises to achieve performance optimization and encourage enterprises to fulfill environmental responsibility actively.

The structure of this paper is as follows: Section 2 presents an overview of related literature and formulates research hypotheses. Section 3 describes the data, sample selection, variables, and our estimation approach. Section 4 presents and discusses the empirical results to test and analyze the hypotheses. The robustness test is presented inj Section 5. The final section summarizes the research results and provides policy recommendations, in addition to outlining future areas of research.

\section{Literature Review and Research Hypotheses}

Enterprises inevitably have an impact on the environment in the course of operation. The incorporation of environmental factors into enterprise management has stimulated significant growth in research on enterprise environmental management in the past few decades. Research on environmental management has established a number of branches and carried out a large number of studies, proving that this issue is increasingly important [6].

Environmental management has externalities, and enterprises usually regard environmental investment as a cost without obvious benefits. If environmental investment only brings extra cost, enterprises will not take the initiative to implement it. Aside from moral constraints, only economic performance incentives can motivate enterprises to fulfill their environmental responsibilities. Therefore, if environmental protection can bring economic benefits and there is no conflict between them, then enterprises will voluntarily take action and assume environmental responsibility.

\subsection{Research on Corporate Environmental Responsibility}

Corporate environmental responsibility is playing an increasingly important role in environmental management. In recent years, research results on corporate environmental responsibility have been abundant, mainly focusing on the following three aspects: First, research on the interaction between corporate environmental responsibility (CER) and economic and social results, such as the impact of CER on enterprise risk [7], operating income [8] and export performance [9], the impact of CER investment on enterprise income distribution [10], the impact of government scale and government supervision on CER [11], etc. Secondly, research on the relationship between corporate environmental responsibility and corporate organizational structure and behavior, such as the social relationship of the board of directors [12], female directors [13], and employees' organizational identity [14]. Finally, research on the driving factors of corporate environmental responsibility, including information disclosure of corporate environmental responsibility [15], environmental NGO certification [16], corporate culture [17], etc. 
More and more literature has focused on reasons for enterprises to participate in environmental responsibility and its impact on economic performance. In many studies, there is a consistent conclusion that corporate environmental responsibility is a source of competitive advantage, which can promote innovation and increase stakeholder value [3,9]. However, we know little about the impact of environmental performance on the economic performance of industrial enterprises when they perform environmental responsibility activities.

\subsection{Research on the Relationship between Environmental Performance and Economic Performance}

In 1989, the British economist David Pearce first proposed the term "Green Economy" in the "Green Economy Blue Book", arguing that the economy and the environment influence each other and that the integration of the environment into capital and investment can help solve the contradiction between economic growth and the environment [18]. Since the 21st century, in the theoretical and empirical literature, the relationship between environmental performance and economic performance has aroused great interest. In practice, including in developing countries, this is also one of the key issues that determine whether enterprises can incorporate environmental protection into their core operations and strategic management systems.

Traditional economic theory states that there is a negative correlation between environmental protection and economic performance; while complying with relevant environmental laws and regulations, the investment of an enterprise's limited resources in non-productive anti-pollution equipment and the reduction in investment in production equipment will reduce productivity [19]. The transaction theory indicates that the environmental protection activities of enterprises will consume the financial resources of enterprises, because the benefits of environmental protection activities cannot offset the costs involved, thus, reducing the economic benefits of enterprises [20]. In addition, the environmental activities of enterprises are in conflict with the main objective of maximizing shareholders' short-term wealth. Voluntary environmental management-related activities are regarded as charitable, which contradicts the principle of profit maximization [21] and increases the risk for enterprises [7]. Filbeck and Gorman found that there is a negative correlation between the environmental performance of companies and the value of stocks [22]. This view challenges those who believe that there is a win-win situation between enterprise interests and environmental protection [23].

At present, many opinions assert that good corporate environmental performance can effectively reduce energy use and waste generation, and enable companies to save costs [3]. Studies have shown that although compliance with environmental regulations will incur additional costs, it can also cut costs in other areas (such as waste treatment technology). The "Porter hypothesis" contends that appropriate environmental regulation will encourage enterprises to adopt advanced technology to reduce environmental costs, improve enterprise performance and market competitiveness, and, thus, establish a competitive advantage for enterprises in the "green market" [23]. Some studies have also explored the factors that promote enterprises' participation in environmental responsibility and their impact on enterprise performance $[2,9,10]$. Hart et al. proposed that the relevant efforts of enterprises to improve environmental performance can create more valuable resources and become a source of competitive advantage $[2,9,10]$. Miles and Covin pointed out that good environmental initiatives can create new opportunities for gaining a better ecological reputation and benefits from premium pricing and increased sales [24].

By adopting an environmentally responsible approach, enterprises can meet the needs of stakeholders who provide resources, such as customers, shareholders, governments, consumers, and community residents, to obtain the resources needed for enterprise development [9]. Hang Song et al. examined the relationship between environmental management and the financial performance of listed companies in China from 2007 to 2011. The results show that environmental management is significantly positively correlated with the next year's financial performance, indicating that environmental management can significantly improve future profitability [25]. Malik Shahzad Shabbir and Okere Wisdom 
studied the relationship between corporate social responsibility, environmental investment, and the financial performance of Nigerian manufacturing enterprises. The results show that enterprises with high environmental investment have higher profitability than environmentally unconscious enterprises [26]. Yun Liu et al. studied the impact of environmental performance on China's financial performance based on the information of Chinese listed companies disclosed in 2008-2017. The results show that fulfilling environmental responsibility can significantly improve corporate financial performance [27].

Regarding empirical research on the relationship between environmental performance and economic performance, some research results are uncertain [28], highlighting the complex relationship between environmental performance and economic performance [29,30]. According to Telle's research, the positive impact of environmental performance on economic performance obtained by hybrid regression was insignificant in a panel econometric study that controlled the data heterogeneity [31]. Li et al. used a sample of 475 listed Chinese companies from 2013 to 2014 to analyze the relationship between environmental performance, environmental information disclosure, and financial performance of Chinese companies. The results show that there is a U-shaped nonlinear relationship between corporate environmental performance and environmental disclosure, and the relationship between environmental performance and financial performance is insignificant [32].

The results of previous studies on the relationship between enterprise environmental performance and economic performance are often inconsistent or even contradictory. At present, most scholars believe that there is a simple linear relationship between enterprise environmental performance and economic performance either positive or negative [33,34], which provides a richer theoretical basis for understanding and explaining the relationship between them.

In general, China is currently in the initial stage of environmental governance. When enterprises begin to actively fulfill their environmental responsibilities, their environmental performance improves, which will have a positive impact on their economic performance. Although the environmental performance of an enterprise will improve with a continuous increase in its environmental input, loss of production and financial resources will inevitably occur when resources are limited. The benefits generated by environmental performance cannot make up for the cost consumed, thus, reducing the economic performance of enterprises.

Based on the above analysis, we believe that the relationship between enterprise environmental performance and economic performance is not a simple linear relationship. With the continuous increase of enterprise environmental performance, the influence on enterprise economic performance may present an inverted U-shaped relationship [35,36]. Therefore, we propose the following hypothesis:

Hypothesis (H1). The impact of environmental performance on economic performance presents an inverted U-shaped relationship.

\section{Data and Measurement of Environmental Performance}

\subsection{Data and Sample Selection}

Enterprises from different industries operate under different degrees of environmental pressure and government supervision, which makes it difficult to accurately compare the environmental performance of enterprises in various industries. Taking a single industry as the research object can effectively eliminate the noise interference of different industries [30]. As an important industry with high pollution, high energy consumption, and high emission in China, iron and steel enterprises have been required to reduce pollution emission and improve efficiency for a long time. Since the iron and steel industry has a great impact on environmental pollution, stakeholders pay more attention to the impact of its environmental performance on economic performance. Therefore, we take iron and steel enterprises as research samples to make the research more realistic and targeted. 
Database and estimation methods are key factors of empirical research. Environmental data used in early research is usually based on ratings or binary data. For example, in order to evaluate the enterprise environmental performance, some scholars use the KLD database, which only provides binary numbers. These databases are limited to calculations using questionnaire survey and expert evaluation methods. The dataset used by Ismail Sila and Kemal Cek relies on the information disclosed in corporate social responsibility reports. This information may sometimes be biased. Enterprises exaggerate the level of their social responsibility practices and create a more positive corporate image for stakeholders [35-37]. Due to the over-reporting of participants and the uncontrollable heterogeneity of enterprises, these studies are often biased. Therefore, based on statistical data from the China Iron and Steel Association, a panel dataset of 54 large enterprises in China's iron and steel industry from 2009 to 2017 was collected. This dataset provides the financial data of large-scale iron and steel enterprises in China, which can be used to more accurately study the impact of enterprise environmental performance on economic performance. These sample enterprises account for more than 50 percent of China's crude steel production.

\subsection{Measuring Enterprise Environmental Performance}

\subsubsection{Measurement Methods}

In this paper, enterprise environmental performance is defined as the degree of impact of enterprise behavior on the environment, that is, the effectiveness of enterprise environmental management. Accurately evaluating environmental performance plays an important role in studying the relationship between environmental performance and economic performance. According to research on quantifying environmental performance, the difficulty in studying the relationship between environmental performance and economic performance lies in the lack of a standard measurement of environmental performance. Most existing studies use subjective content analysis [15] and questionnaire survey methods $[38,39]$. Incorporating resources and environmental factors in environmental performance evaluation has always been a focus of the academic community. The DEA method is an effective analysis measurement tool, which is widely used [40-42]. Wu et al. used a two-stage DEA model to study China's energy issues and environmental performance evaluation [43]. When conducting enterprise-level environmental efficiency evaluation research, the DEA method is better than the parameterized method. This is because the production conditions of enterprises in various countries or regions vary greatly. In this case, matching parameter relationships between the inputs and outputs of different enterprises may lead to deviations in practice. Therefore, the DEA method is more popular in enterprise-level research [44]. To further improve the research mechanism of quantifying environmental performance, we use the DEA method to measure the environmental performance of enterprises, which is of great significance for establishing objective evaluation standards and fully understanding the relationship between environmental performance and economic performance.

Data Envelopment Analysis (DEA) is an evaluation method based on the concept of relative efficiency, using convex analysis and linear programming as tools. This method uses a mathematical programming model to calculate and compare the relative efficiency between decision-making units and evaluate the evaluation objects. It can fully consider the optimal input-output scheme for the decision-making unit itself, and can better reflect the information and characteristics of the evaluation object. The original DEA model measures the efficiency score of the decision-making unit (DMU) based on inputs and desired outputs (such as income, profitability, and production). When it comes to pollution such as greenhouse gas emissions, wastewater, and poorly produced solid waste, the traditional method of only considering the expected output is no longer applicable. To overcome the limitations of the original data envelopment analysis method, some scholars have proposed a data envelopment analysis method that includes undesired output. Due to the disadvantages and complexity of the traditional DEA model configuration, Slack- 
based measurement (SBM) has become the mainstream of current research [40]. The maximum efficiency value obtained by the standard DEA model is 1 , the effective DMU efficiency value is the same, and the efficiency of these effective DMUs cannot be further distinguished. In order to solve this problem, Andersen and Petersen proposed a method to further distinguish the effective degree of effective DMU. This method is called the "super-efficiency" model [45]. For further research, we combined the SBM model with undesired outputs and the "super-efficiency" model to form an SBM super-efficiency model with undesired outputs. The planning formula of the model is as follows:

$$
\begin{gathered}
\min \rho=\frac{1+\frac{1}{m} \sum_{i=1}^{m} A_{i}^{-} / x_{i k}}{1-\frac{1}{q_{1}+q_{2}}\left(\sum_{r=1}^{q_{1}} A_{r}^{+} / y_{r k}+\sum_{t=1}^{q_{2}} A_{t}^{b-} / b_{t k}\right)} \\
\text { S. t. } \sum_{j=1, j \neq k}^{n} x_{i j} \lambda_{j}-A_{i}^{-} \leq x_{i k} \\
\sum_{j=1, j \neq k}^{n} y_{i j} \lambda_{j}-A_{r}^{+} \geq y_{r k} \\
\sum_{j=1, j \neq k}^{n} b_{t j} \lambda_{j}-A_{t}^{b-} \leq b_{t k} \\
\frac{1}{q_{1}+q_{2}}\left(\sum_{r=1}^{q_{1}} A_{r}^{+} / y_{r k}+\sum_{t=1}^{q_{2}} A_{t}^{b^{-}} / b_{t k}\right)>0 \\
\lambda_{j}, \mathrm{~A}_{i}^{-}, \mathrm{A}_{r}^{+} \geq 0 \\
i=1,2, \cdots, m ; r=1,2, \cdots, q ; j=1,2, \cdots, n(j \neq k)
\end{gathered}
$$

In Model (1), it is assumed that there are $n$ decision-making units, and each decisionmaking unit has an input vector, an expected output vector, and an undesired output vector. Assuming that there are $m$ types of inputs and $q$ types of outputs, including $q_{1}$ expected outputs and $q_{2}$ undesired outputs, the input vector is $x \in \mathrm{R}^{m}$, the expected output vector is $y \in \mathrm{R}^{q 1}$, and the undesired output vector is $b \in \mathrm{R}^{q 2}$. Where $\mathrm{S}$ represents the slack of input and output, $A^{-}$represents the input redundancy, $A^{+}$represents the expected output shortage, $A^{\mathrm{b}-}$ represents the undesired output excess, $\lambda$ is the weight vector, and $\rho$ represents the efficiency score.

\subsubsection{Description of Measurement Variables}

According to the research purpose and the situation of China's iron and steel industry, the indicators listed in Table 1 were selected.

Variable selection and interpretation are shown in Table 1. The input variables include new water consumption, fixed assets, number of employees, energy consumption, and environmental protection investment. The output value of three wastes utilization is an expected output variable, and the waste residue, waste gas, waste water, and pollutant discharge fees are undesired output variables.

Among the input variables, assets and labor are traditional input variables for research efficiency. On this basis, this paper focuses on the environmental performance of iron and steel enterprises, so new water consumption, energy consumption, and environmental protection investment variables are added to make the investment indicators more comprehensive. The undesired output variables include waste residue, waste gas, and waste water, which are the main pollutants discharged by enterprises, while the discharge fee reflects the degree of government supervision of enterprises and highlights the government's supervisory role. The desirable output variable selects the output value of the three wastes, which indicates the degree of utilization of pollutants by the enterprise and fully reflects 
the degree of importance that the enterprise attaches to environmental management. The descriptive statistics of variables are shown in Table 2.

Table 1. Variable selection and interpretation.

\begin{tabular}{|c|c|c|}
\hline Variable & & Interpretation \\
\hline \multirow[t]{5}{*}{ Inputs } & New water consumption & $\begin{array}{l}=\text { total water consumption } \times(1-\text { water resource } \\
\text { reuse rate })\end{array}$ \\
\hline & Fixed assets & $\begin{array}{l}=\text { the original value of the fixed assets }- \text { the } \\
\text { accumulated depreciation }- \text { the provision for } \\
\text { impairment of fixed assets }\end{array}$ \\
\hline & Number of employees & Average number of employees per year \\
\hline & Energy consumption & $\begin{array}{l}\text { A unified conversion of various energy consumption } \\
\text { into standard coal consumption }\end{array}$ \\
\hline & Environmental protection investment & Amount of investment for environmental protection \\
\hline \multirow[t]{4}{*}{ Undesired outputs } & Waste residue & $\begin{array}{l}\text { Total amount of waste residue produced } \\
\text { by enterprises }\end{array}$ \\
\hline & Waste gas & Total amount of waste gas produced by enterprises \\
\hline & Waste water & $\begin{array}{l}\text { Total amount of waste water produced } \\
\text { by enterprises }\end{array}$ \\
\hline & Pollutant discharge fees & $\begin{array}{l}\text { Fees paid to the government according to the type, } \\
\text { quantity and concentration of pollutants discharged }\end{array}$ \\
\hline Expected output & Output value of three wastes utilization & $\begin{array}{l}\text { Refers to the value of products produced using the } \\
\text { "three wastes" (waste water, waste gas, and waste } \\
\text { residue) as the main raw materials }\end{array}$ \\
\hline
\end{tabular}

Table 2. Descriptive statistics of input and output variables for iron and steel enterprises (2009-2017).

\begin{tabular}{cccccc}
\hline Variable & Units & Mean & Std. Dev. & Min & Max \\
\hline New water consumption & Ten thousand $\mathrm{m}^{3}$ & 2729.62 & 2198.23 & 228.56 & $11,495.04$ \\
Fixed assets & Billion Yuan & 208.11 & 204.07 & 7.93 & 1177.92 \\
Number of employees & Thousand people & 20.49 & 19.20 & 1.90 & 140.00 \\
Energy consumption & Ten thousand tons & 438.11 & 344.00 & 24.51 & 2062.20 \\
Environmental protection investment & Ten thousand Yuan & $18,685.37$ & $33,853.49$ & 25.00 & $268,939.00$ \\
Waste residue & Ten thousand tons & 462.65 & 450.14 & 1.64 & 2682.52 \\
Waste gas & Hundred million m m $^{3}$ & 1585.38 & 1423.30 & 0.06 & 7976.02 \\
Waste water & Million m m $^{3}$ & 517.65 & 569.41 & 1.20 & 3760.80 \\
Pollutant discharge fees & Ten thousand Yuan & 2504.16 & 2443.92 & 179.08 & $14,690.21$ \\
Output value of three wastes & Ten thousand Yuan & $58,957.63$ & $84,670.18$ & 275.00 & $595,652.00$ \\
utilization & & & &
\end{tabular}

\subsubsection{Measurement Results}

According to existing research and through careful analysis of the actual environmental management situation of the enterprises included in the sample, this study takes the waste residue, waste gas, waste water, and pollutant discharge fees as the environmental undesired output of iron and steel enterprises. Among them, the emission of three wastes is the main output variable affecting the environmental performance of enterprises. In addition, pollutant discharge fees are levied by regulators, which are also the variables of most concern for regulators; pollutant discharge fees are another output variable that affects the environmental performance of enterprises.

This study calculates the input and output data of iron and steel enterprises in the environment through the SBM super-efficiency model including undesired outputs, and uses the EP to express the results. It provides objective and effective data for examining 
the relationship between the environmental performance and economic performance of enterprises. The calculation results are described in detail in Table 3. EP1-3 input variables are the same, but output variables are different. Among them, EP1 indicates that the undesired output variables include the three wastes (waste residue, waste gas, and waste water) and pollutant discharge fees. EP2 indicates that the undesired output variables only include the three wastes. EP3 indicates that the undesired output variables include only the pollutant discharge fees.

Table 3. Summary statistics.

\begin{tabular}{|c|c|c|c|c|c|c|}
\hline Variable Name & Variable Symbol & Obs & Mean & Std. Dev. & Min & Max \\
\hline Return on assets & ROA & 486 & 1.487 & 4.247 & -23.338 & 11.828 \\
\hline Environmental performance 1 & EP1 & 486 & 0.534 & 0.311 & 0.006 & 1.250 \\
\hline Environmental performance 2 & EP2 & 486 & 0.514 & 0.331 & 0.005 & 1.333 \\
\hline Environmental performance 3 & EP3 & 486 & 0.417 & 0.365 & 0.002 & 1.739 \\
\hline Enterprise scale & $\operatorname{lnScale}$ & 486 & 15.080 & 0.948 & 11.956 & 17.006 \\
\hline Factor endowment structure & Fes & 486 & 11.091 & 8.104 & 0.410 & 49.560 \\
\hline Total operating cost & $\operatorname{lnTC}$ & 486 & 14.926 & 0.849 & 12.018 & 17.009 \\
\hline Main business income & $\operatorname{lnMBI}$ & 486 & 14.853 & 0.870 & 11.902 & 17.022 \\
\hline Asset liability ratio & Leverage & 486 & 68.735 & 13.562 & 32.200 & 120.660 \\
\hline
\end{tabular}

As can be seen from Table 3, the results of EP1, EP2, and EP3 are significantly different. Therefore, it is reasonable to separate the three wastes and pollutant discharge fees to measure the environmental performance of iron and steel enterprises. This makes it possible to explore the impact of environmental performance on economic performance in more detail, which is also one of the main contributions of this paper.

\section{Research Design}

\subsection{Model Building}

This study focuses on the impact of environmental performance on economic performance. In order to make an empirical analysis of the above hypothesis, we used the environmental panel data of 54 large-scale enterprises in China's iron and steel industry from 2009 to 2017. On this basis, we constructed the Environmental Performance Index (EP) to measure corporate environmental responsibility, and conducted an empirical test on the relationship between environmental performance and economic performance. Referring to the research of Cai et al. (2016), Liang et al. (2017), and Xu et al. (2018) [1,7,9], combined with the research hypothesis proposed in this study, we propose the following econometric equation model:

$$
\begin{aligned}
\text { ROA }_{i, t}= & \alpha_{0}+\alpha_{1} E P 1_{i, t-1}+\alpha_{2}\left(E P 1_{i, t-1}\right)^{2}+\alpha_{3} \ln \text { Scale }_{i, t}+\alpha_{4} \text { Fes }_{i, t}+\alpha_{5} \ln T C_{i, t} \\
& +\alpha_{6} \ln M B I_{i, t}+\alpha_{7} \text { Leverage }_{i, t}+\mu_{i, t} \\
\text { ROA }_{i, t}= & \beta_{0}+\beta_{1} E P 2_{i, t-1}+\beta_{2}\left(E P 2_{i, t-1}\right)^{2}+\beta_{3} \ln \text { Scale }_{i, t}+\beta_{4} \text { Fes }_{i, t}+\beta_{5} \ln T C_{i, t} \\
& +\beta_{6} \ln M B I_{i, t}+\beta_{7} \text { Leverage }_{i, t}+\theta_{i, t} \\
\text { ROA }_{i, t}= & \delta_{0}+\delta_{1} E P 3_{i, t-1}+\delta_{2}\left(E P 3_{i, t-1}\right)^{2}+\delta_{3} \ln \text { Scale }_{i, t}+\delta_{4} \text { Fes }_{i, t}+\delta_{5} \ln T C_{i, t} \\
& +\delta_{6} \ln M B I_{i, t}+\delta_{7} \text { Leverage }_{i, t}+\eta_{i, t}
\end{aligned}
$$

In the above model, $i$ represents the enterprise and $t$ represents the time (2009-2017). $\alpha_{0} \sim \alpha_{7}, \beta_{0} \sim \beta_{7}$, and $\delta_{0} \sim \delta_{7}$ are parameters to be estimated. $\theta_{i, t}, \eta_{i, t}$, and $\mu_{i, t}$ are the random disturbance terms. Scale, Fes, TC, MBI, and Leverage are the set of control variables.

\subsection{Variable Description}

The dependent variable in this paper is the return on assets (ROA). ROA refers to the ratio of after-tax net profit to total assets, which is used to measure the net profit created by each unit of assets of an enterprise. The higher the index, the stronger the profitability of 
the enterprise. Return on assets is considered as the best measure of enterprise economic performance and is widely used [12,15].

The independent variable is environmental performance (EP). In this study, the SBM super-efficiency model including undesired outputs is used to evaluate the state of environmental inputs and outputs of iron and steel enterprises, and the evaluation results are expressed by environmental performance. Among them, EP1 indicates that the undesired output variables include the measurement results of three wastes (waste residue, waste gas, and waste water) and pollutant discharge fees, EP2 indicates that the undesired output variables only include the measurement results of three wastes, and EP3 indicates that the undesired output variables only include the measurement results of pollutant discharge fees. Since the impact of corporate environmental behavior on corporate economic performance often has a lag effect, we conducted an empirical test based on the lagging stage of EP.

There were also some control variables. Scale of the enterprise (Scale) is measured by the natural logarithm of total assets at the end of the year. The factor endowment structure (Fes) is expressed by the ratio of the enterprise's net fixed assets to the enterprise's annual average number of employees. The higher the Fes is, the more capital-intensive the enterprise is, which is more conducive to the improvement of production technology and the economic performance of an enterprise. Total operating cost (TC) refers to the total cost of goods sold or services provided by an enterprise, which is used to control the impact of the total investment of the enterprise on the economic performance of the enterprise. Main business income (MBI) refers to the operating income obtained by the enterprise from the production and operation activities of the industry. This paper also considers the impact of financial leverage on the enterprise, using the enterprise's year-end asset-liability ratio (leverage) to measure the financial leverage [9]. Table 3 presents the summary statistics for all variables.

In Table 3, the environmental performance (EP) represents the environmental performance of Chinese iron and steel enterprises. Among them, the maximum value of EP1 is 1.25 and the average value is 0.534; the maximum value of EP2 is 1.333 and the average value is 0.514 ; the maximum value of EP3 is 1.739 and the average value is only 0.417 . This means that the environmental performance of Chinese steel companies is quite varied, and the overall environmental management level is low.

\section{Empirical Analysis}

\subsection{Empirical Result Analysis}

Based on the panel data, the three models, namely, the fixed-effects model, randomeffects model, and mixed-model were comprehensively considered in the model selection. By comparing the regression results of the three models, the fixed effects model is determined as the optimal model. The regression results of the fixed effects model are shown in Table 4.

Through controlling the fixed effects of enterprises, we essentially explore how the economic performance of enterprises in the same industry changes with changes in environmental performance. The specific regression results are shown in Table 4 . The results demonstrate that enterprise environmental performance $\left(\mathrm{EP}_{\mathrm{t}-1}\right)$ has a significant positive correlation with ROA, but the estimated coefficient of the square term of enterprise environmental performance $\left(\mathrm{EP}_{\mathrm{t}-1}{ }^{2}\right)$ is significantly negative. Therefore, there is a significant inverted U-shaped relationship between enterprise environmental performance and return on assets. That is, in the initial stage, the continuous improvement of the environmental performance of iron and steel enterprises will improve their economic performance, but when the environmental performance exceeds the critical value, it will have a negative impact on economic performance. 
Table 4. Regression analysis results.

\begin{tabular}{|c|c|c|c|}
\hline $\begin{array}{c}\text { Models } \\
\text { Variables }\end{array}$ & $\begin{array}{c}(1) \\
\text { ROA }\end{array}$ & $\begin{array}{c}(2) \\
\text { ROA }\end{array}$ & $\begin{array}{c}(3) \\
\text { ROA }\end{array}$ \\
\hline$E P 1_{t-1}$ & $\begin{array}{c}7.68^{* * *} \\
(2.77)\end{array}$ & & \\
\hline$\left(E P 1_{t-1}\right)^{2}$ & $\begin{array}{l}-4.43^{* *} \\
(-2.43)\end{array}$ & & \\
\hline $\mathrm{EP} 2_{\mathrm{t}-1}$ & & $\begin{array}{c}6.65^{* * *} \\
(2.79)\end{array}$ & \\
\hline$\left(E P 2_{t-1}\right)^{2}$ & & $\begin{array}{c}-4.31 * * * \\
(-2.61)\end{array}$ & \\
\hline$E P 3_{t-1}$ & & & $\begin{array}{l}3.77 \text { * } \\
(1.93)\end{array}$ \\
\hline$\left(\mathrm{EP} 3_{\mathrm{t}-1}\right)^{2}$ & & & $\begin{array}{l}-2.65 * \\
(-1.94)\end{array}$ \\
\hline $\operatorname{lnScale}$ & $\begin{array}{c}-0.05 \\
(-0.05)\end{array}$ & $\begin{array}{c}-0.09 \\
(-0.18)\end{array}$ & $\begin{array}{c}-0.05 \\
(-0.12)\end{array}$ \\
\hline Fes & $\begin{array}{c}0.00 \\
(0.05)\end{array}$ & $\begin{array}{c}0.00 \\
(0.05)\end{array}$ & $\begin{array}{c}0.00 \\
(0.15)\end{array}$ \\
\hline $\operatorname{lnTC}$ & $\begin{array}{c}-3.71 * * * \\
(-4.36)\end{array}$ & $\begin{array}{c}-3.63^{* * *} \\
(-4.33)\end{array}$ & $\begin{array}{c}-3.73^{* * *} \\
(-4.25)\end{array}$ \\
\hline $\operatorname{lnMBI}$ & $\begin{array}{c}4.52 * * * \\
(5.22)\end{array}$ & $\begin{array}{c}4.51 \text { *** } \\
(5.18)\end{array}$ & $\begin{array}{c}4.39 * * * \\
(5.13)\end{array}$ \\
\hline Leverage & $\begin{array}{c}-0.21 * * * \\
(-8.43)\end{array}$ & $\begin{array}{c}-0.21 * * * \\
(-8.43)\end{array}$ & $\begin{array}{c}-0.21^{* * *} \\
(-8.39)\end{array}$ \\
\hline Constant & $\begin{array}{c}4.11 \\
(0.44) \\
\end{array}$ & $\begin{array}{c}4.92 \\
(0.51) \\
\end{array}$ & $\begin{array}{c}5.48 \\
(0.57) \\
\end{array}$ \\
\hline $\begin{array}{l}\mathrm{N} \\
R^{2}\end{array}$ & $\begin{array}{c}432 \\
0.318\end{array}$ & $\begin{array}{c}432 \\
0.318\end{array}$ & $\begin{array}{c}432 \\
0.309\end{array}$ \\
\hline
\end{tabular}

Notes: $\mathrm{t}$ statistics in parentheses. ${ }^{* * *},{ }^{* *}$, and ${ }^{*}$ denote the statistical significance at the $0.01,0.05$, and 0.10 levels, respectively.

Specifically, according to Model (1), the impact of enterprise environmental performance $\left(E P 1_{t-1}\right)$ on return on assets (ROA) is 7.68 , which is significant at the level of $1 \%$, while the impact of the square term of enterprise environmental performance $\left(E P 1_{t-1}{ }^{2}\right)$ is -4.43 , which is significant at the level of $5 \%$. This shows that there is a significant inverted U-shaped relationship between enterprise environmental performance $\left(\mathrm{EP}_{\mathrm{t}-1}\right)$ and return on assets with undesired output variables (waste residue, waste gas, and waste water) and pollutant discharge fees, which supports the theoretical hypothesis.

According to Model (2), the impact of enterprise environmental performance $\left(E P 2_{t-1}\right)$ on return on assets is 6.65 , which is significant at the level of $1 \%$, while the estimated coefficient of the square term of enterprise environmental performance $\left(\mathrm{EP}_{\mathrm{t}-1}{ }^{2}\right)$ is -4.31 , which is significant at the level of $1 \%$. This indicates that there is a significant inverted U-shaped relationship between enterprise environmental performance $\left(\mathrm{EP}_{\mathrm{t}-1}\right)$ and return on assets when the undesired output variable is only three wastes. It also supports the hypothesis proposed above.

According to Model (3), the impact of enterprise environmental performance $\left(\mathrm{EP}_{\mathrm{t}-1}\right)$ on the rate of return on assets is 3.77 , which is significant at the level of $10 \%$, while the estimated coefficient of the square term of enterprise environmental performance $\left(\mathrm{EP}_{\mathrm{t}-1}{ }^{2}\right)$ is -2.65 , which is significant at the level of $10 \%$. This indicates that there is a significant inverted U-shaped relationship between enterprise environmental performance $\left(\mathrm{EP}_{\mathrm{t}-1}\right)$ only including pollution charges fees and return on assets, which also offer supporting evidence for the hypothesis in this paper. 
By comparing $\mathrm{EP} 1_{t-1}, E P 2_{t-1}$, and $E P 3_{t-1}$, it is found that considering different environmental undesired output variables in the environmental performance of enterprises has different effects on economic performance. Among them, considering the environmental performance of three wastes (waste residue, waste gas, and waste water) has a greater impact on the economic performance of enterprises than pollutant discharge fees.

The results of Models (1)-(3) show that the impact of the environmental performance of Chinese iron and steel enterprises on economic performance presents an inverted U-shaped relationship. This indicates that the impact of enterprise environmental performance on economic performance can be divided into two stages. First, with the continuous improvement of enterprise environmental performance, the contribution of environmental performance to economic benefits has gradually increased. This may be because the current environmental problems in China are becoming increasingly serious. Government policies and the demands of stakeholders, such as consumers, employees, and media, are pressuring enterprises to improve environmental performance and assume environmental responsibility. This will reduce the operating cost and risk for enterprises, improving their legitimacy and reputation, creating competitive advantages [3,9], and improving their economic performance. However, with further improvements in enterprise environmental performance and increasing investment in the environment, more limited resources are allocated to non-productive environmental protection, which erodes investment in productive resources and leads to a decrease in enterprise economic performance. This is because the capital, resources, and management capacity of enterprises are usually limited. Therefore, increasing the investment in environmental protection will inevitably reduce the investment in normal production management, thus reducing the financial performance.

The regression results of control variables show that there is a significant positive correlation between main business income and return on assets. There is a significant negative correlation between total operating cost, asset-liability ratio, and return on assets. There is a small positive correlation between the factor endowment structure of an enterprise and the return on assets, but the result is not significant. While there is a negative correlation between enterprise size and return on assets, but the result is not significant. It shows that the main business income has a significant promoting effect on the economic performance of enterprises, while the total operating cost and the asset-liability ratio have a significant inhibiting effect on the economic performance of enterprises. The factor endowment structure of the enterprise has no significant promotion effect on the economic performance, and the scale of the enterprise has an inhibitory effect on the economic performance but is not significant.

The above analysis shows that the performance of environmental responsibilities by enterprises has a non-linear effect on economic performance, and it also shows that the performance of environmental responsibilities by enterprises has a lagging effect. This means that environmental management is a long-term investment process, and enterprises must weigh environmental performance and economic performance at the same time, and establish long-term environmental strategies and plans.

\subsection{Robustness Checks}

In order to test the robustness of the above regression results, we used the dynamic system GMM model and the two-stage least squares method (2SLS) for a robustness test.

\subsubsection{Dynamic System GMM Test}

The GMM dynamic panel model is often used as a robustness test. In order to solve the endogenous problems caused by reverse causality, simultaneity, and omitted variables, we refer to the method of Cai et al. for the GMM test of the dynamic panel system [7]. The results are shown in Table 5. 
Table 5. Dynamic system GMM regression results.

\begin{tabular}{|c|c|c|c|}
\hline $\begin{array}{c}\text { Models } \\
\text { Variables }\end{array}$ & $\begin{array}{c}(4) \\
\text { ROA }\end{array}$ & $\begin{array}{c}(5) \\
\text { ROA }\end{array}$ & $\begin{array}{c}(6) \\
\text { ROA }\end{array}$ \\
\hline$E P 1_{t-1}$ & $\begin{array}{c}17.88^{* * *} \\
(5.43)\end{array}$ & & \\
\hline$\left(E P 1_{t-1}\right)^{2}$ & $\begin{array}{c}-11.93^{* * *} \\
(-4.28)\end{array}$ & & \\
\hline $\mathrm{EP} 2_{\mathrm{t}-1}$ & & $\begin{array}{c}16.13^{* * *} \\
(5.63)\end{array}$ & \\
\hline$\left(\mathrm{EP} 2_{\mathrm{t}-1}\right)^{2}$ & & $\begin{array}{c}-10.58^{* * *} \\
(-4.86)\end{array}$ & \\
\hline$E P 3_{t-1}$ & & & $\begin{array}{l}3.42 * \\
(1.72)\end{array}$ \\
\hline$\left(E P 3_{t-1}\right)^{2}$ & & & $\begin{array}{l}-2.56 * \\
(-1.77)\end{array}$ \\
\hline $\mathrm{ROA}_{\mathrm{t}-1}$ & $\begin{array}{c}0.01 \\
(0.02)\end{array}$ & $\begin{array}{c}-0.02 \\
(-0.28)\end{array}$ & $\begin{array}{c}-0.03 \\
(-0.75)\end{array}$ \\
\hline $\mathrm{ROA}_{\mathrm{t}-2}$ & $\begin{array}{l}-0.09 * \\
(-1.81)\end{array}$ & $\begin{array}{l}-0.09 * \\
(-1.88)\end{array}$ & $\begin{array}{l}-0.12 * * \\
(-2.38)\end{array}$ \\
\hline $\mathrm{ROA}_{\mathrm{t}-3}$ & $\begin{array}{c}0.16^{* * *} \\
(3.27)\end{array}$ & $\begin{array}{c}0.16^{* * *} \\
(3.31)\end{array}$ & $\begin{array}{l}0.08^{* *} \\
(2.15)\end{array}$ \\
\hline $\operatorname{lnScale}$ & $\begin{array}{c}2.12 * * * \\
(3.07)\end{array}$ & $\begin{array}{c}2.08^{* * *} \\
(3.17)\end{array}$ & $\begin{array}{l}1.61^{* *} \\
(2.44)\end{array}$ \\
\hline Fes & $\begin{array}{c}0.01 \\
(1.03)\end{array}$ & $\begin{array}{c}0.01 \\
(1.11)\end{array}$ & $\begin{array}{c}0.01 \\
(1.45)\end{array}$ \\
\hline $\ln \mathrm{TC}$ & $\begin{array}{l}-2.36 \\
(-2.02)\end{array}$ & $\begin{array}{l}-2.41^{* *} \\
(-2.12)\end{array}$ & $\begin{array}{c}-2.77^{* * *} \\
(-2.77)\end{array}$ \\
\hline $\ln \mathrm{MBI}$ & $\begin{array}{c}3.17^{* * *} \\
(2.85)\end{array}$ & $\begin{array}{c}3.21^{* * *} \\
(2.93)\end{array}$ & $\begin{array}{c}3.63^{* * *} \\
(3.49)\end{array}$ \\
\hline Leverage & $\begin{array}{c}-0.18 * * * \\
(-5.80)\end{array}$ & $\begin{array}{c}-0.18 \text { *** } \\
(-5.95)\end{array}$ & $\begin{array}{c}-0.18^{* * *} \\
(-4.86)\end{array}$ \\
\hline Constant & $\begin{array}{c}-35.22 * * * \\
(-3.25)\end{array}$ & $\begin{array}{c}-34.78^{* * *} \\
(-3.22)\end{array}$ & $\begin{array}{c}-26.36 \\
(-2.28)\end{array}$ \\
\hline $\mathrm{N}$ & 324 & 324 & 324 \\
\hline AR(1) test ( $p$-value) & 0.0003 & 0.0003 & 0.0001 \\
\hline AR(2) test ( $p$-value) & 0.632 & 0.378 & 0.265 \\
\hline Hansen test ( $p$-value) & 0.172 & 0.349 & 0.235 \\
\hline
\end{tabular}

Notes: $\mathrm{t}$ statistics in parentheses. ${ }^{* * *},{ }^{* *}$, and ${ }^{*}$ denote the statistical significance at the $0.01,0.05$, and 0.10 levels, respectively.

Based on the estimation results of the GMM dynamic panel model, the $p$ values of the $\operatorname{AR}(2)$ test and the over-restricted Hansen test exceed the levels of $1 \%, 5 \%$, and $10 \%$, which cannot reject the original hypothesis that there is no second-order sequence correlation and the original hypothesis that the tool is effective. This means that the inverted U-shaped relationship between environmental performance and return on assets is not driven by simultaneity bias. The results in Table 5 show that corporate environmental performance $\left(\mathrm{EP}_{\mathrm{t}-1}, \mathrm{EP} 2_{\mathrm{t}-1}\right.$, and $\left.\mathrm{EP} 3_{\mathrm{t}-1}\right)$ has a positive and significant relationship with return on assets, but the square term of corporate environmental performance has a negative and significant relationship with return on assets. This confirms the inverted U-shaped relationship between environmental performance and economic performance 
of China's iron and steel enterprises, thus providing strong support for the hypothesis proposed in this paper.

\subsubsection{Two-Stage Least Squares Test}

Authors of previous studies concluded that enterprise environmental performance is an endogenous variable, and the environmental performance (EP) variable is associated with a disturbance term, which makes OLS estimation biased and inconsistent [9]. In order to alleviate the endogenous concern driven by simultaneity and reverse causality, we use the instrumental variable method to test the causal effect of environmental performance (EP) on economic performance. Taking environmental performance (EP) with a lag of 2 years and a lag of 3 years as instrumental variables, the regression results of the two-stage least squares method are shown in Table 6.

Table 6. Two-stage least squares regression results.

\begin{tabular}{|c|c|c|c|}
\hline $\begin{array}{c}\text { Models } \\
\text { Variables }\end{array}$ & $\begin{array}{c}(7) \\
\text { ROA }\end{array}$ & $\begin{array}{c}(8) \\
\text { ROA }\end{array}$ & $\begin{array}{c}(9) \\
\text { ROA }\end{array}$ \\
\hline$E P 1_{t-1}$ & $\begin{array}{c}47.37 * \\
(1.71)\end{array}$ & & \\
\hline$\left(E P 1_{t-1}\right)^{2}$ & $\begin{array}{c}-30.23 \\
(-1.66)\end{array}$ & & \\
\hline$E P 2_{t-1}$ & & $\begin{array}{c}36.12 * \\
(1.79)\end{array}$ & \\
\hline$\left(\mathrm{EP} 2_{\mathrm{t}-1}\right)^{2}$ & & $\begin{array}{l}-22.56 \text { * } \\
(-1.81)\end{array}$ & \\
\hline$E P 3_{t-1}$ & & & $\begin{array}{l}12.59 * \\
(1.67)\end{array}$ \\
\hline$\left(\mathrm{EP}_{\mathrm{t}-1}\right)^{2}$ & & & $\begin{array}{l}-7.82 * \\
(-1.66)\end{array}$ \\
\hline $\ln S$ cale & $\begin{array}{c}1.55 \\
(1.21)\end{array}$ & $\begin{array}{c}1.32 \\
(1.09)\end{array}$ & $\begin{array}{c}0.61 \\
(0.67)\end{array}$ \\
\hline Fes & $\begin{array}{c}0.02 \\
(0.92)\end{array}$ & $\begin{array}{c}0.02 \\
(0.96)\end{array}$ & $\begin{array}{c}0.02 \\
(1.09)\end{array}$ \\
\hline $\operatorname{lnTC}$ & $\begin{array}{l}-3.42^{* *} \\
(-2.38)\end{array}$ & $\begin{array}{l}-3.17 * * \\
(-2.33)\end{array}$ & $\begin{array}{l}-2.60 * * \\
(-1.99)\end{array}$ \\
\hline $\ln M B I$ & $\begin{array}{l}3.12 * * \\
(2.28)\end{array}$ & $\begin{array}{l}3.08^{* *} \\
(2.17)\end{array}$ & $\begin{array}{l}3.14^{* *} \\
(2.39)\end{array}$ \\
\hline Leverage & $\begin{array}{c}-0.27 \text { *** } \\
(-5.36)\end{array}$ & $\begin{array}{c}-0.27^{* * *} \\
(-5.44)\end{array}$ & $\begin{array}{c}-0.24^{* * *} \\
(-4.25)\end{array}$ \\
\hline $\mathrm{N}$ & 324 & 324 & 324 \\
\hline First-stage $\mathrm{F}$ test & 0.000 & 0.000 & 0.000 \\
\hline Hansen test ( $p$-value) & 0.682 & 0.901 & 0.245 \\
\hline
\end{tabular}

Notes: $\mathrm{t}$ statistics in parentheses. ${ }^{* * *},{ }^{* *}$, and ${ }^{*}$ denote the statistical significance at the $0.01,0.05$, and 0.10 levels, respectively.

The ideal instrumental variable should be highly correlated with environmental performance $\left(\mathrm{EP}_{\mathrm{t}-1}\right)$ and not directly correlated with the return on assets (ROA) of the explained variable. The selection of instrumental variables was tested through the first stage $\mathrm{F}$ test, and the test results are consistent with the hypothesis. The first stage $\mathrm{F}$ test results are significant, indicating that the selected instrumental variables meet the correlation hypothesis. Through the Hansen test, the tested $p$ values also exceed the $1 \%, 5 \%$, and $10 \%$ levels, and the null hypothesis that the tool is valid cannot be rejected. Table 6 reports the detailed test results. The results show that the impact of enterprise environmental 
performance $\left(E P 1_{t-1}, E P 2_{t-1}\right.$, and $\left.E P 3_{t-1}\right)$ and return on assets is positive significantly, while the influence of the square term of environmental performance and return on assets is significantly negative. It is confirmed that the impact of environmental performance on economic performance of Chinese iron and steel enterprises presents an inverted U-shaped relationship, and the robustness of the results is further supported.

\section{Conclusions and Suggestions}

Enterprises are facing various forms of constraints in environmental management in China. On the one hand, despite an increase in environmental regulation and related laws in recent years, Chinese enterprises are still at an early stage of environmental protection compared with Western developed countries. The senior managers of Chinese enterprises did not show a positive attitude towards environmental management. On the other hand, all stakeholders have conflicting expectations of the environmental management and sustainability of enterprises. They not only agree that the sustainable development of enterprises requires investment in environmental protection, but also worry about the negative impact on the enterprises' economic interests. Therefore, based on the samples of large iron and steel enterprises in China from 2009 to 2017, this study explores the impact of enterprise environmental performance on economic performance, and links enterprise environmental responsibility with strategic and financial objectives. The results show that there is an inverted U-shaped relationship between environmental performance and economic performance.

The key contribution of this research to analyzing the internal process between environmental performance and economic performance, and identifying incentive factors, so that environmental performance evaluation can improve the competitiveness of enterprises. This will continue to encourage enterprises to improve their environmental performance. Enterprise environmental responsibility not only leads to efficient economic behavior but also incorporates conservation and the protection of environmental resources. Therefore, enterprises should balance the relationship between environmental performance and economic performance in order to maximize their performance. Based on this, the following policy recommendations are provided:

First, the government should be aware of the important role that enterprises play in environmental governance by fulfilling environmental responsibilities and should ensure that enterprises comply with environmental laws. This is an effective way to guide enterprises to carry out environmental governance. It has been proven that environmental supervision can enhance the environmental performance of enterprises with a sense of environmental responsibility.

Second, in terms of environmental responsibility, Chinese enterprises are still in a passive state, either in concept or in practice. They are often under pressure from the government, society, and partners in the industrial chain, and ignore the benefits and competitiveness brought by environmental responsibility. It is vital for enterprises to change their mindset and take environmental responsibility. On one hand, enterprises should strengthen the concept of environmental responsibility and make it a part of the corporate culture. Having a proactive corporate environmental responsibility culture is rapidly becoming a source of competitive advantage for many enterprises. On the other hand, establishing an environmental information disclosure system is necessary for enterprises. In this way, enterprises can be put under the supervision of the public, to protect the public's right to know about environmental issues.

In this paper, we only use data from China and do not conduct a comparative study with companies from developed economies. Therefore, in other economies with different political and economic systems, the interpretation of the results should be cautious, and further discussion may be needed. In addition, the reasons for the varying environmental performance of enterprises in the same industry should also be explored. Future research can explore the role of senior managers, especially their vision of environmental sustain- 
ability, and analyze the impact of management in encouraging enterprises to fulfill their environmental responsibilities.

Author Contributions: Conceptualization, R.L.; Data curation, R.L.; Methodology, F.H.; Software, J.R.; Writing-original draft, R.L. All authors have read and agreed to the published version of the manuscript.

Funding: This research was supported by the National Natural Science Foundation of China (Grant Number 71673022), Tsinghua University-Inditex Sustainable Development Fund (Grant Number TISD201902), and the Fundamental Research Funds for the Central Universities (Grant Number FRF-BR-19-006A).

Institutional Review Board Statement: Not applicable.

Informed Consent Statement: Not applicable.

Data Availability Statement: The datasets used during the current study are available from the China Iron and Steel Industry Association (http:/ / www.chinaisa.org.cn. Accessed on 26 December 2020). The datasets generated and analyzed during the current study are available from the corresponding author on reasonable request.

Conflicts of Interest: The authors declare no conflict of interest.

\section{References}

1. Liang, D.; Liu, T. Does environmental management capability of Chinese industrial firms improve the contribution of corporate environmental performance to economic performance? Evidence from 2010 to 2015. J. Clean. Prod. 2017, 142, 2985-2998. [CrossRef]

2. Hart, S.L. A Natural-Resource-Based View of the Firm. Acad. Manag. Rev. 1995, 20, 986-1014. [CrossRef]

3. Chuang, S.; Huang, S. The Effect of Environmental Corporate Social Responsibility on Environmental Performance and Business Competitiveness: The Mediation of Green Information Technology Capital. J. Bus. Ethics 2018, 150, 991-1009. [CrossRef]

4. Deng, X.; Li, L. Promoting or Inhibiting? The Impact of Environmental Regulation on Corporate Financial Performance-An Empirical Analysis Based on China. Int. J. Environ. Res. Public Health 2020, 17, 3828. [CrossRef]

5. Wu, H.; Lv, K.; Liang, L.; Hu, H. Measuring performance of sustainable manufacturing with recyclable wastes: A case from China's iron and steel industry. Omega 2017, 66, 38-47. [CrossRef]

6. Jiménez-Parra, B.; Alonso-Martínez, D.; Godos-Díez, J. The influence of corporate social responsibility on air pollution: Analysis of environmental regulation and eco-innovation effects. Corp. Soc. Responsib. Environ. Manag. 2018, 25, 1363-1375. [CrossRef]

7. Cai, L.; Cui, J.; Jo, H. Corporate Environmental Responsibility and Firm Risk. J. Bus. Ethics 2016, 139, 563-594. [CrossRef]

8. Wong, C.W.Y.; Miao, X.; Cui, S.; Tang, Y. Impact of Corporate Environmental Responsibility on Operating Income: Moderating Role of Regional Disparities in China. J. Bus. Ethics 2018, 149, 363-382. [CrossRef]

9. Xu, X.; Zeng, S.; Chen, H. Signaling good by doing good: How does environmental corporate social responsibility affect international expansion? Bus. Strateg. Environ. 2018, 27, 946-959. [CrossRef]

10. Ee, M.S.; Chao, C.; Wang, L.F.S.; Yu, E.S.H. Environmental corporate social responsibility, firm dynamics and wage inequality. Int. Rev. Econ. Financ. 2018, 56, 63-74. [CrossRef]

11. Graafland, J. Economic freedom and corporate environmental responsibility: The role of small government and freedom from government regulation. J. Clean. Prod. 2019, 218, 250-258. [CrossRef]

12. Zou, H.; Xie, X.; Qi, G.; Yang, M. The heterogeneous relationship between board social ties and corporate environmental responsibility in an emerging economy. Bus. Strateg. Environ. 2019, 28, 40-52. [CrossRef]

13. Wei, F.; Ding, B.; Kong, Y. Female Directors and Corporate Social Responsibility: Evidence from the Environmental Investment of Chinese Listed Companies. Sustainability 2017, 9, 2292. [CrossRef]

14. Petridou, P.G.A.E. Corporate social responsibility and pro-environmental behaviour: Organisational identification as a mediator. Eur. J. Int. Manag. 2017, 11, 1-8.

15. Ali, W.; Frynas, J.G.; Mahmood, Z. Determinants of Corporate Social Responsibility (CSR) Disclosure in Developed and Developing Countries: A Literature Review. Corp. Soc. Responsib. Environ. Manag. 2017, 24, 273-294. [CrossRef]

16. Zhao, L.; Du, J. Certification of Environmental Corporate Social Responsibility Activities in Differentiated Duopoly Market. Math. Probl. Eng. 2017, 2017, 1-7. [CrossRef]

17. Peng, B.; Tu, Y.; Wei, G. Can Environmental Regulations Promote Corporate Environmental Responsibility? Evidence from the Moderated Mediating Effect Model and an Empirical Study in China. Sustainability 2018, 10, 641. [CrossRef]

18. Pearce, D.; Markandya, A.; Barbier, E. Blueprint 1: For a Green Economy; Routledge: London, UK, 1989.

19. Haveman, R.H.; Christainsen, G.B. Environmental Regulations and Productivity Growth. Nat. Resour. J. 1981, $21,489-509$.

20. Waddock, S.A.; Graves, S.B. The Corporate Social Performance-Financial Performance Link. Strateg. Manag. J. 1997, 18, 303-319. [CrossRef] 
21. Zhi, T.; Tang, J. Stakeholder-firm power difference, stakeholders' CSR orientation, and SMEs' environmental performance in China. J. Bus. Ventur. 2012, 27, 436-455.

22. Filbeck, G.; Gorman, R.F. The Relationship between the Environmental and Financial Performance of Public Utilities. Environ. Resour. Econ. 2004, 29, 137-157. [CrossRef]

23. Porter, M.E.; Claas, V.D.L. Toward a New Conception of the Environment-Competitiveness Relationship. J. Econ. Perspect. 1995, 9 , 97-118. [CrossRef]

24. Miles, M.P.; Covin, J.G. Environmental Marketing: A Source of Reputational, Competitive, and Financial Advantage. J. Bus. Ethics 2000, 23, 299-311. [CrossRef]

25. Song, H.; Zhao, C.; Zeng, J. Can environmental management improve financial performance: An empirical study of A-shares listed companies in China. J. Clean. Prod. 2017, 141, 1051-1056. [CrossRef]

26. Shabbir, M.S.; Wisdom, O. The relationship between corporate social responsibility, environmental investments and financial performance: Evidence from manufacturing companies. Environ. Sci. Pollut. R 2020, 27, 39946-39957. [CrossRef]

27. Liu, Y.; Xi, B.; Wang, G. The impact of corporate environmental responsibility on financial performance-Based on Chinese listed companies. Environ. Sci. Pollut. R 2021, 28, 7840-7853. [CrossRef] [PubMed]

28. Torugsa, N.A.; Donohue, W.O.; Hecker, R. Proactive CSR: An Empirical Analysis of the Role of its Economic, Social and Environmental Dimensions on the Association between Capabilities and Performance. J. Bus. Ethics 2013, 115, 383-402. [CrossRef]

29. Corbett, C.J.; Klassen, R.D. Extending the Horizons: Environmental Excellence as Key to Improving Operations. Manuf. Serv. Oper. Manag. 2006, 8, 5-22. [CrossRef]

30. Tang, Z.; Tang, J. Stakeholder Corporate Social Responsibility Orientation Congruence, Entrepreneurial Orientation and Environmental Performance of Chinese Small and Medium-sized Enterprises. Brit. J. Manag. 2018, 29, 634-651. [CrossRef]

31. Telle, K. “It Pays to be Green"-A Premature Conclusion? Environ. Resour. Econ. 2006, 35, 195-220. [CrossRef]

32. Li, D.; Zhao, Y.; Sun, Y.; Yin, D. Corporate environmental performance, environmental information disclosure, and financial performance: Evidence from China. Hum. Ecol. Risk Assess. 2016, 23, 323-339. [CrossRef]

33. Han, S.; You, W.; Nan, S. Zombie firms, external support and corporate environmental responsibility: Evidence from China. J. Clean. Prod. 2019, 212, 1499-1517. [CrossRef]

34. Wei, Z.; Shen, H.; Zhou, K.Z. How Does Environmental Corporate Social Responsibility Matter in a Dysfunctional Institutional Environment? Evidence from China. J. Bus. Ethics 2017, 140, 209-223. [CrossRef]

35. Jin, G.; Yu, B.; Shen, K. Domestic trade and energy productivity in China: An inverted U-shaped relationship. Energy Economics 2021, 97, 105234. [CrossRef]

36. Zhang, J.; Kang, L.; Li, H.; Pablo, B.P.; Martin, S.; Zuo, J. The impact of environmental regulations on urban Green innovation efficiency: The case of Xi'an. Sustain. Cities Soc. 2020, 57, 102123. [CrossRef]

37. Sila, I.; Cek, K. The Impact of Environmental, Social and Governance Dimensions of Corporate Social Responsibility on Economic Performance: Australian Evidence. Procedia Comput. Sci. 2017, 120, 797-804. [CrossRef]

38. Dey, P.K.; Petridis, N.E.; Petridis, K.; Malesios, C.; Nixon, J.D.; Ghosh, S.K. Environmental management and corporate social responsibility practices of small and medium-sized enterprises. J. Clean. Prod. 2018, 195, 687-702. [CrossRef]

39. Peng, B.; Tu, Y.; Elahi, E.; Wei, G. Extended Producer Responsibility and corporate performance: Effects of environmental regulation and environmental strategy. J Environ. Manag. 2018, 218, 181-189. [CrossRef] [PubMed]

40. Wang, G.; Li, K.X.; Xiao, Y. Measuring marine environmental efficiency of a cruise shipping company considering corporate social responsibility. Mar. Policy 2019, 99, 140-147. [CrossRef]

41. Chen, L.; Jia, G. Environmental efficiency analysis of China's regional industry: A data envelopment analysis (DEA) based approach. J. Clean. Prod. 2017, 142, 846-853. [CrossRef]

42. Chen, L.; He, F.; Zhang, Q.; Jiang, W.; Wang, J. Two-stage efficiency evaluation of production and pollution control in Chinese iron and steel enterprises. J. Clean. Prod. 2017, 165, 611-620. [CrossRef]

43. Wu, J.; Xiong, B.; An, Q.; Sun, J.; Wu, H. Total-factor energy efficiency evaluation of Chinese industry by using two-stage DEA model with shared inputs. Ann. Oper. Res. 2017, 255, 257-276. [CrossRef]

44. Wang, Y.; Wen, Z.; Cao, X.; Zheng, Z.; Xu, J. Environmental efficiency evaluation of China's iron and steel industry: A process-level data envelopment analysis. Sci. Total. Environ. 2020, 707, 135903. [CrossRef] [PubMed]

45. Andersen, P.; Petersen, N.C. A Procedure for Ranking Efficient Units in Data Envelopment Analysis. Manag. Sci. 1993, 39, 1261-1264. [CrossRef] 